Research Paper

\title{
Research on Improving Logistics Efficiency in the Iraqi Oil and Gas Industry
}

HyUngSuK LEe

Corresponding author: mcyijhl6@gmail.com

School of Business, Pusan National University

Busan, Republic of Korea

\section{About the author}

Hyungsuk Lee received his $\mathrm{Ph}$. D in Business Administration from Pusan National University, Republic of Korea. He has been working at Korea Gas Corporation (KOGAS) as the team leader of the logistics department for the Iraqi oil and gas projects since May 2013. He also had the experience of working with LG electronics in UAE from September 2008 to May 2013 and managing supply chain for Gulf Cooperation Council (GCC) and Caspian countries. His research interest includes logistics, supply chain management, and data envelopment analysis. 


\section{abstract}

Currently, many international companies in Iraq struggle to implement successful oil and gas projects caused by poor logistics. Although dramatic progress is required, improvements in logistics are proceeding at a very slow pace. This research identifies the current logistics status in the Iraqi oil \& gas industry and measures the relative efficiency of Iraq logistics in comparison with 157 countries using the two-stage DEA model: the first stage evaluates the efficiency of supply chain service delivery, and the second stage measures the national logistics efficiency in the local economy. The overall efficiency of national logistics is also measured. Then, the author provides practical recommendations on how to improve logistics and the economy based on the results of efficiency score, return to scale (RTS), reference set and DEA projection value. This study suggests that Iraq should reengineer its customs processes, increase its investment on infrastructure, and improve the quality of its service in order to attract more global logistics service providers.

Keywords:Iraqi Logistics, National Logistics Efficiency, Two-stage DEA Model

\section{Introduction}

Logistics is becoming the backbone of international trade and commerce as a result of the increasing globalization of the manufacturing supply chain. The importance of good logistics performance for economic growth, diversification, and poverty reduction is now firmly established (Arvis et al., 2014). Logistics competency is a key capability in all industries (Keebler and Plank 2009). Efficient logistics is able to transport materials efficiently for the economy (Marti, Puertas and Garcia, 2014). Therefore, it contributes significantly to national competitiveness and supply chain management (SCM) is considered a key strategy for most companies.

It is necessary to understand the logistics performance at the country level in order to evaluate the policy target and the efforts in policy-making across countries. (Rantasila and Ojala, 2015). Effective logistics performance plays a critical role in international materials transportation and is crucial in attracting foreign investment. Logistics inefficiencies are the bottleneck of an organization's productivity in terms of foreign investment climate and trade facilitation. Such bottleneck degrades organizations' competitiveness in cost and time (Hausman, Lee and Subramanian, 2013).

The comparison of supply chains, as one of the influential factors related to the business environment, is important in two aspects. Firstly, supply chain owners and managers can identify the strengths and weaknesses of their supply chain systems and improve their advantages through comparison with the best performers from different facets. Secondly, supply chain ranking can be accomplished through accurate comparisons based on suitable criteria. Proper supply chain ranking serves as persuasive evidence to show company owners and managers their competitive positions among all the competitors (Jalalvand et al., 2011).

Keebler and Plank (2009) suggest three reasons for measuring logistics performance. Firstly, companies can reduce operating costs, increase revenue and thus enhance shareholder value. Secondly, companies can 
attract new customers and retain valuable customers through cost reduction and service improvement, and thus improve the price value of the products they offer. Finally, logistics performance improvement has a significant impact on stock returns and the market value of a company.

Iraq has a huge potential as one of the world's largest oil exporters and has achieved impressive economic progress in recent years despite the political and religious violence, bureaucratic inefficiencies and corruptions. Many global companies consider Iraq a promising market for investment. However, many international oil and gas companies struggle in importing materials from Iraq due to its inefficient customs system and the lack of infrastructure. Logistics is one of the biggest bottlenecks for any successful business project in Iraq.

This research investigates the current situations and efficiency of logistics in Iraq and makes comparison with other countries using a two-stage Data Envelopment Analysis (DEA) model. The purpose is to present and develop practical ideas for improving logistics performance in the Iraqi oil and gas industry. There are very few studies on Iraqi logistics and this preliminary attempt aims to act as the foundation for further logistics study in this country.

The target of this study is to examine a project with Midland Oil Company (MdOC) under the Iraqi Ministry of Oil. The two-stage DEA model is used to analyze the national logistics efficiency as the empirical methodology. DEA has been used to measure the performance of various industries since its first introduction by Charnes, Cooper, and Rhodes (1978). According to Cook and Zhu (2006), DEA is a conventional methodology for revealing the real world through quantitative data analysis. Cook, Kress and Seiford (1996) investigate the application of both quantitative and qualitative factors to the DEA approach and measures its ability to model a structure. They stress the usefulness of DEA as an effective tool to solve problems in a broad range.

The literature regarding DEA has increased in recent years due to the rapid growth of research in this field (Liu et al., 2013). However, its applicability in supply chain performance measurement has not been reported so far and it is worthwhile to extend its application to the field of SCM (Wong and Wong, 2007). Wong and Wong (2008) recommend DEA for evaluating supply chain performance measurement because its flexibility functions as a competitive tool in benchmarking analysis and can contribute to longterm organizational performance management. Cook, Tone and Zhu (2014) used DEA for performance evaluation and benchmarking against best practice. DEA is able to identify benchmarking targets for inefficient decision-making units (DMUs). Under general benchmarking, the DEA score may no longer be referred to as "production efficiency" . It may be employed as a form of the "overall performance" of an organization (Zhu, 2014).

This research can be compared with studies conducted by Arvis et al. (2014) and Wang (2014), as both articles examined national logistics efficiency and performance. Arvis et al. (2014) survey six indicators (customs, infrastructure, service quality, timeliness, international shipments and tracing \& tracking) and aggregate the six scores into one single indicator (Logistics Performance Index: LPI) using a weighted average. They use LPI to evaluate the performance of different countries, regions and income groups. Iraq ranks 141st out of the 160 countries. But no specific country-wise analysis is provided. Meanwhile, Wang's (2014) DEA analysis of cross-country logistics efficiency is restricted by the poor data availability.to only 27 
countries, none in the Middle East region. She suggests that less developed countries should increase their investment whereas developed countries need to rationalize their national logistics systems.

This research is structured as follows. Firstly, it investigates the current logistics status in the Iraqi oil and gas industry. Secondly, it describes the DEA methodology used in this study. Thirdly, it analyzes the national logistics efficiency and presents recommendations for improving the logistics of the Iraqi oil and gas industry. Finally, it summarizes the main conclusions and makes suggestions on the avenues for future research.

\section{Current Status of Logistics in the Iraqi Oil and Gas Industry}

\section{Customs}

\section{Shipping Documentation Requirements}

Iraq requires a number of documents for customs clearance and all information on shipping documentation must be accurate. Required shipping documents include commercial invoice, packing list, certificate of origin, bill of lading, levy and tax exemption letter, 1st delivery order (from liner agent), 2nd delivery order (from Iraqi maritime transport), 3rd party inspection report (exemption depending on agreements with Iraq), relevant import approval from Iraq authorities (in case of controlled items: chemical materials, armoured vehicles, communication equipment, etc.), and import license (exemption depending on agreements with Iraq). Commercial invoice and packing list should be displayed with Arabic translation on the same page. Commercial invoice and certificate of origin should be legalized from the Iraqi embassy in the country of origin. The import type (permanent or temporary) should also be declared on the documentation. The name and the number of the contracts with the Iraqi government should be clearly indicated in the shipping documents.

Endorsement of Shipping Documents and Customs Clearance in the Iraqi Oil and Gas Industry

Before processing customs clearance, required documents need to be submitted to the Iraqi authority (i.e., $\mathrm{MdOC}$ ), which is also the ordering authority of the oil and gas projects. The endorsement process for permanent and temporary imports is described as in Fig. 1. They have different customs clearance routes and take a long time since all the required documents are hand-carried to the designated departments without any online systems available for processing. Furthermore, the customs clearance process inside the port is

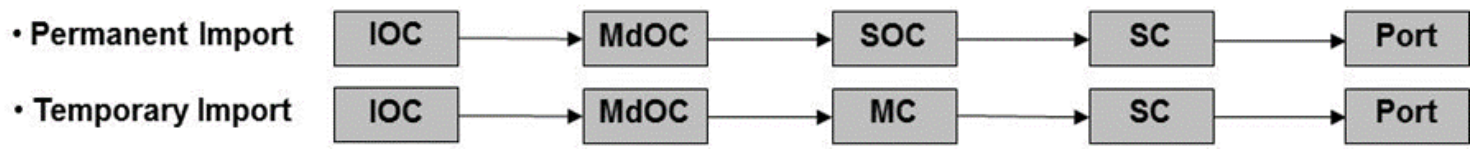

Fig. 1 Shipping Documents Endorsement Process

Notes: IOC (International Oil Company), MdOC (Midland Oil Company), SOC (South Oil Company), SC (South-region Customs) and MC (Middle-region Customs). 
also very slow, because many departments are involved and they are handling without any effective assistance system.

\section{Levy and Tax Exemption}

All international oil and gas companies in Iraq are entitled to exemption from the reconstruction levy and tax when importing materials and equipment from abroad. But it takes a long time to obtain the approvals from the relevant authority organizations due to their inefficient workflow. The top priority with the Iraqi oil and gas project may serve as a substitute for the official shipping documents of customs clearance.

In order to go through the levy and tax exemption process, the list of the equipment and materials to be imported must be approved by MdOC first. Then it is submitted to the relevant authorities for further approval. The whole process is described in Fig. 2. The several steps in obtaining the approvals usually take a long time. This exemption approval process is also one of the big bottlenecks of customs clearance in the Iraqi oil and gas industry.

- Levy Exemption

- Tax Exemption

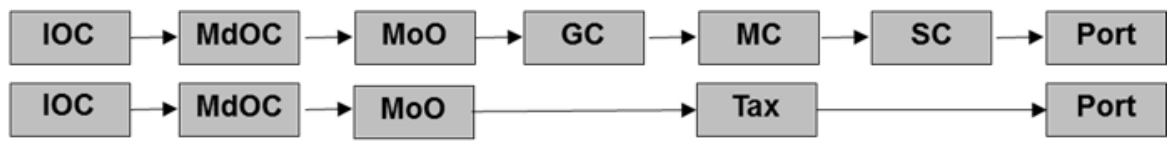

Fig. 2 Levy and Tax Exemption Approval Process

\section{Controlled Items}

In the case of importing radioactive materials, communication equipment, chemical materials, armoured vehicles and medical materials, special approvals from the relevant Iraqi authorities should be obtained before importation. For example, the importation of armoured vehicles must be approved by the Ministry of Interior (MOI), medical materials by the Ministry of Health $(\mathrm{MOH})$ and communication equipment by the Communication and Media Commission (CMC). All purchase and import of such materials and equipment are well-planned in advance, but the approval application process may be delayed for a long time since it is completely unpredictable.

\section{Others}

In addition to the aforementioned issues, there are several problematic factors in the procedure for import and export in Iraq. For example, some equipment needs to be exported to other countries for maintenance after being imported to Iraq. This is caused by the unavailability of most maintenance facilities within the country. But since the export approval is required and there is no clear written procedure for the application from many Iraqi authorities, the export process is extremely difficult.

There are strict regulations on shipping documentation for customs clearance in Iraq which may not be required in advanced countries. For example, Iraq requires legalization on all commercial invoices and certificates of origin, which must be attested by the Iraqi embassy in the country of origin. In fact, many 
countries do not require document authentication and legalization for customs clearance in export-import business. This increases the cost for international companies and impedes the swift flow of cargoes.

In the case of payment to the customs of Iraq, companies are always required to pay through bank transfer. This is not only for the purpose of smooth customs operation, but also to avoid potential corruption. Bank transfer may take extra days before the whole customs clearance process to be over.

\section{Infrastructure}

\section{Ports}

There are several gateways for imported materials and equipment into Iraq. Fig. 3 shows the major entry points for the oil and gas projects under MdOC.

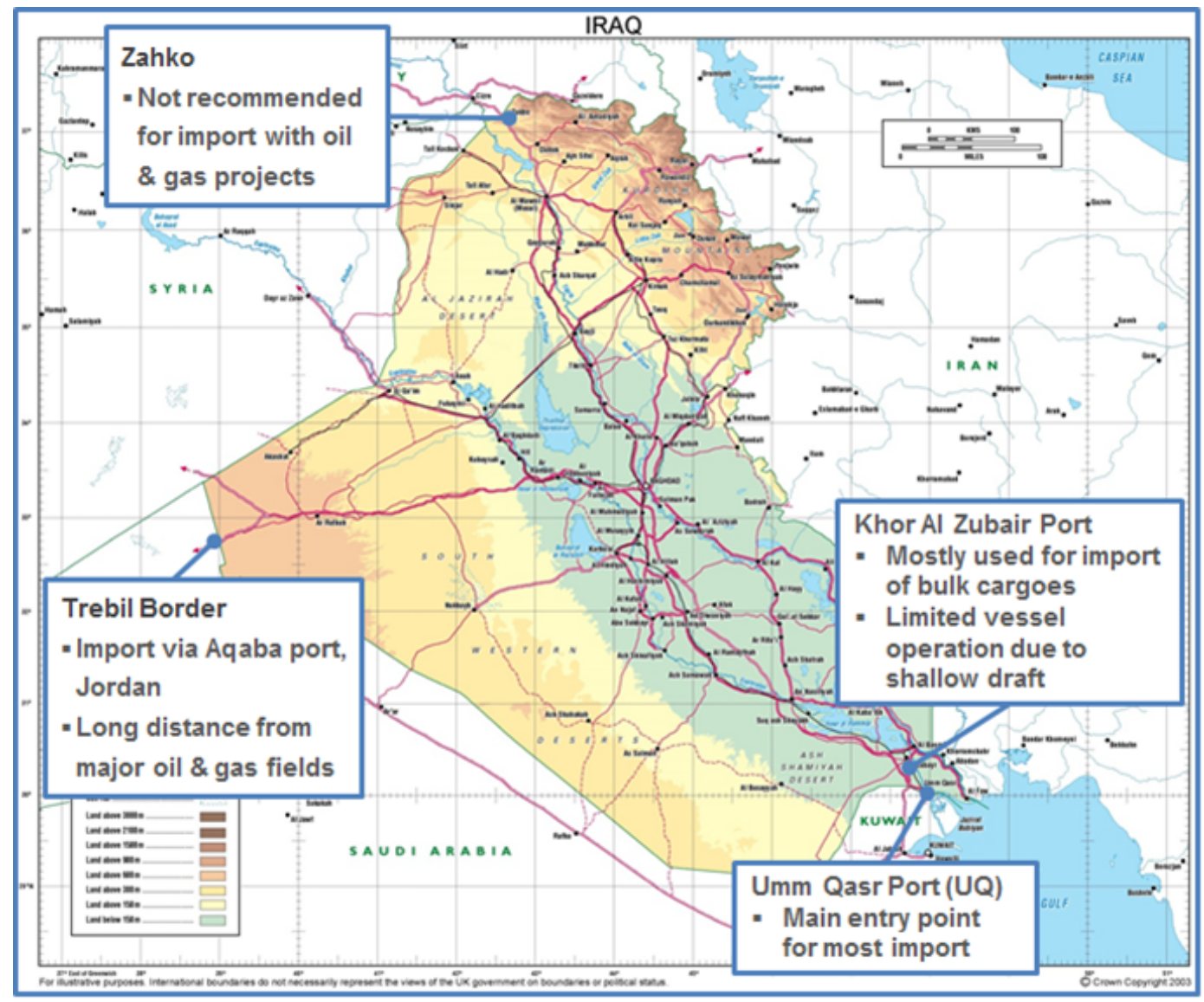

Fig. 3 Main Entry Points in Iraq

Most materials and equipment are imported through Umm Qasr (UQ) port, where major international shipping liners are operating. However, the equipment is obsolete and no sufficient equipment is available for the operation, thus, the port is heavily congested. Meanwhile, Khor Al Zubair port has the relatively modern equipment and the Iraqi government recommends companies use this port in order to avoid heavy congestion at Umm Qasr (UQ). But international shipping liners do not reach Khor Al Zubair port due to 
the inadequate berthing depths at the terminals. Companies are also suggested to import materials and equipment via Aqaba port in Jordan and transport the goods across the Trebil border. But the distance is too far from major oil and gas fields in Iraq and it is almost impossible to use this route at the current stage due to the security problem. The Zahko border is not recommended by the Ministry of Oil because it is located in the Kurdistan region where different customs regulations have been instigated by the Kurdish regional government.

In all, the port operation systems in Iraq are under-developed and the operation process is inefficient. Furthermore, the ports lack in qualified personnel to handle the work. The government is not taking adequate measures to improve the efficiency of the port work. The annual capacity of the terminals in Iraq is 15 million tons in 2013 while the forecast of future demand is approximately 53 million tons in 2018 (Iraqi Ministry of Planning, 2013).

\section{Roads}

The quality of roads in Iraq was relatively good before 2003. However, roads in many regions were damaged and destroyed as a result of the military conflicts in 2003. This led to the inefficiency of the road network throughout the country. In addition, many traffic signs were also damaged or disappeared. Thus, road rehabilitation is one of the priorities for the improvement work (Iraqi Ministry of Planning, 2013). Current roads need to be expanded to cover more rural areas. More traffic signs need to be installed in many places. Thus, a proper budget is required for the maintenance and rehabilitation of roads.

\section{Airports}

In the case of some urgent cargoes, international oil and gas companies import them by air. Currently, Iraq has six international airports, and reconstruction and rehabilitation are underway to modernize these airports. But the restoration work is very slow. Many staffs have not received professional training and are not qualified for their work at airports. Due to lack of specialists, the airport operations do not meet international standards in Iraq but the demand for air transportation has been increasing in recent years (Iraqi Ministry of Planning, 2013).

\section{Railways}

Due to the outdated design and malfunctioning of the signals and communication systems, large parts of the current railway network in Iraq are obsolete and suffer from the excessive work load. The train operations drop to low levels and the passengers and freight are exposed to danger. Thus, the railways around the country need to be restored and renovated to boost performance and improve their operation specifications (Iraqi Ministry of Planning, 2013).

Railway is most efficient for the economical transportation of freight over long distances and in large quantities. Due to the geographic location of Iraq between East Asia and Europe, railway plays an important role in transporting cargoes to neighbouring countries. The quantity of transit freight projected to be transported through Iraqi ports to Turkey and Europe is estimated to be 35 million tons per year 
approximately as a typical case and 60 million tons in its best-case scenario. Thus, Iraqi railway network needs to be developed and modernized. (Iraqi Ministry of Planning, 2013).

\section{Services Quality}

Logistics operation in Iraq is usually managed by local logistics service providers and the quality of logistics performance is relatively poor compared to advanced countries. Sometimes, there are severe delays in delivery and serious damage to the cargoes. Meanwhile, the logistics professionals are not well-trained. Systematic training is in urgent demand to improve service quality. Moreover, the government should encourage global logistics companies to do business in Iraq and ensure the logistics services are competitive rather than inclusive. The involvement of third-party providers will enhance the development of the logistics service in a country (Arvis et al., 2014).

\section{Data Envelopment Analysis (DEA) Model}

Data Envelopment Analysis (DEA) is an approach developed by Charnes, Cooper, and Rhodes (1978) and has expanded in terms of theory, methodology and application over the past decades. DEA has been recognized as a powerful tool to find efficient Decision-Making Units (DMUs) and to identify the benchmarking process (Reiner and Hofmann, 2006). DEA is non-parametric approach and its major advantage is to measure the efficiency of the performance by considering multiple outputs and inputs. DEA provides sources of inefficiency for inefficient DMUs and figures out the projection value of each variable which enables the DMUs to be efficient. DEA is also able to identify benchmarking targets for inefficient DMUs. Therefore, DEA is used for analysis in this study.

DMU is defined as the organization and can be bank, hospital, schools and so forth (Cooper, Seiford and Tone, 2007). Despite the advantage of DEA in measuring the efficiency with consideration of the multiple inputs and outputs, few studies have applied this method to practical research (Chaowarat, Piboonrugnroj and Shi 2013). In general, there are two directions to measure efficiency: input-oriented and output-oriented. The input-oriented model aims to minimize inputs while keeping the given outputs at their current levels. It is appropriate for identifying DMUs that are over-utilizing resources. The output-oriented model attempts to maximize outputs without any extension of the observed input values. It intends to achieve efficiency from the perspective of how to enhance the output (Cooper, Seiford and Tone, 2006; Cook, Tone and Zhu 2014).

\section{CCR Model}

The CCR (Charnes-Cooper-Rhodes) model was initially developed by Charnes, Cooper, and Rhodes in 1978. It assumes a constant return to scale $(R T S)$. The following output-oriented $C C R$ model is used to handle the logistics performance problem, where $\theta$ refers to the $C C R$ efficiency and its value is less than or equal to 
1.

$\operatorname{Max} \theta$

s.t. $x_{0}-X \lambda \geq 0$

$\theta y_{0}-Y \lambda \leq 0$

$\lambda \geq 0$

Where,

8: $C C R$ efficiency of $D M U_{0}$

$x_{o}, y_{o}$ : Vectors of inputs and outputs of $D M U_{0}$

$X, Y$ : Matrics of inputs and outputs of entire $D M U_{0}$

$\lambda$ : Weight Vector

According to the above equations, the lower the value of $\theta$, the less efficient a $D M U$ is. A $D M U$ is efficient if and only if the optimal value $\theta$ is equal to 1 . If not, the $D M U_{0}$ is inefficient. In case of inefficient $D M U_{s}$, more efficient $D M U_{s}$ exist. These $D M U_{s}$ refer to the reference set to the inefficient ones. As the inefficient units are projected onto the envelopment surface, these targets defined by the efficient projection give an indication of how this $D M U$ can be improved in order to be efficient.

\section{BCC Model}

Since the very beginning of studies on $D E A$, various extensions of the $C C R$ model have been proposed. The $B C C$ (Bank-Charnes-Cooper) model developed by Bank, Charnes, and Cooper (1984) is a representative of such an extension. The $B C C$ model assumes a variable RTS (Return to Scale) because it has the production frontiers spanned by the convex hull of the existing $D M U s$. The input-oriented $B C C$ model is treated in the following logistics performance problem, where $e$ is a row vector, and all elements equal to 1 .

$$
\begin{aligned}
& \text { Min } \eta \\
& \text { s.t. } x_{0}-X \lambda \geq 0 \\
& \eta y_{0}-Y \lambda \leq 0 \\
& e \lambda=1 \\
& \lambda \geq 0
\end{aligned}
$$

Where,

$\eta: B C C$ efficiency of $D M U_{0}$

$x_{o}, y_{o}$ : Vectors of inputs and outputs of $D M U_{0}$

$X, Y$ : Matrics of inputs and outputs of entire $D M U_{0}$

$e$ : Row Vector 


\section{$\lambda$ : Weight Vector}

$\eta$ refers to the $B C C$ efficiency and its value is less than 1. $B C C$ differs from the $C C R$ model due to the convexity condition that the size of the reference set is limited to 1 . In other words, it includes the increasing $R T S$ (IRS), the constant RTS (CRS), and the decreasing RTS (DRS) by adding the constraint ' $e \lambda=1$ '.

\section{Efficiency Decomposition}

In this section, the efficiency is decomposed by using $\theta$ and $\lambda$ to investigate the sources of the inefficiency (Cooper, Seiford and Tone, 2006). The scale efficiency $(S E)$ of a $D M U$ is measured using $S E=\theta / \lambda$. It is less than or equal to 1 because the $C C R$ efficiency is less than or equal to the $B C C$ efficiency. The $C C R$ efficiency is called the technical efficiency $(T E)$ since it takes no account of the scale-effect, while the $B C C$ efficiency is called the pure $T E(P T E)$ due to the assumption that the $R T S$ is variable. If a $D M U$ is fully effective in its $C C R$ and $B C C$ scores, it is operating on being the most productive scale-size. Using these concepts, the decomposition of efficiency is demonstrated in the Equation (8). In other words, the sources of inefficiency are caused by either the inefficient operation of a DMU or the disadvantageous conditions, or by both.

$$
T E=P T E \times S E
$$

Where,

TE: Technical Efficiency

PTE: Pure Technical Efficiency

$S E$ : Scale Efficiency

\section{National Logistics Efficiency Evaluation}

\section{Research Model}

The two-stage DEA model for national logistics efficiency evaluation is shown as in Fig. 4. It includes three stages.

Stage 1: Arvis et al. (2014) define the input variables as 'area for policy regulation' and the output variables as 'service delivery performance'. Therefore, the stage- 1 model is used to evaluate the efficiency of supply chain service delivery, i.e., a country's ability to generate service delivery performance by policy regulation in a specific area. In this study, customs, infrastructure and service quality are employed as input variables, while timeliness, international shipments, and tracing \& tracking are employed as outputs.

Stage 2: Arvis et al. (2014) find a positive correlation between logistics performance and GDP. Wang (2014) uses GDP per capita to evaluate cross-country logistics efficiency. The stage-2 model is used to 


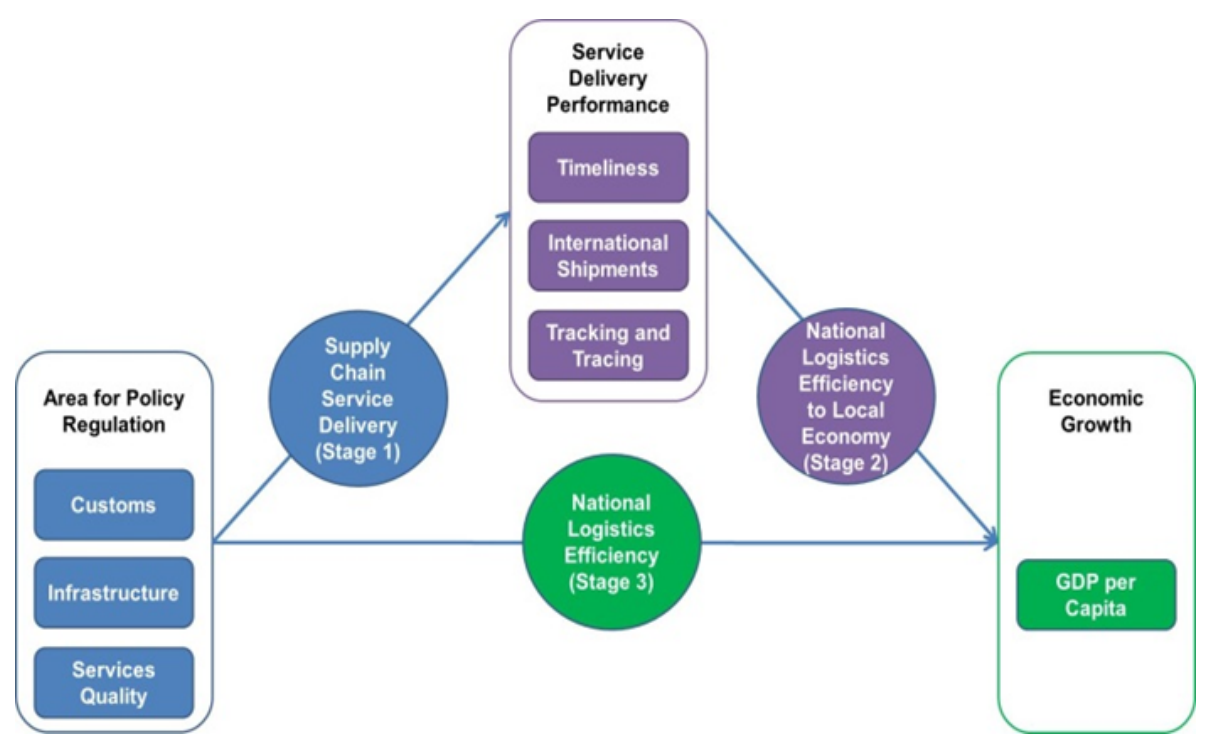

Fig. 4 Two-stage DEA Model for National Logistics Efficiency (Arvis et al., 2014)

evaluate the national logistics efficiency to the local economy, i.e., a country's performance to generate GDP (Gross Domestic Product) by service delivery performance. The outputs of Stage 1 are used as the inputs of Stage 2. GDP per capita is used as the output.

Stage 3: Stage 3 evaluates the overall national logistics efficiency through policy regulation (inputs of Stage 1) as the input variable and GDP (output of Stage 2) as the output variable.

\section{Variables and Data}

Table 1 shows 7 variables used in this study. Arvis et al. (2014) select 6 variables, (i.e., customs, infrastructure, service quality, timeliness, international shipments and tracing \& tracking) to develop LPI (Logistic Performance Index) based on recent theoretical and empirical research. Each of these six variables was surveyed in 2013 by logistics professionals working at internatio0nal logistics companies in 143 countries. Score values for the 6 variables are scaled from 1 to 5 , with 5 representing the highest score and 1 the lowest (Arvis et al., 2014). Furthermore, data for 'GDP per capita' in 2013 is taken from the data of the World Bank and is presented in US dollars.

The 'Customs' variable means the efficiency of customs clearance, i.e. the speed of customs clearance, simplicity, and predictability of the customs formalities. It plays a very important role in the improvement of the service delivery performance. Lu and Lin (2012) evaluate the national logistics performance in Taiwan, Vietnam, and Malaysia. Simplifying customs clearance procedures is considered the most important item for the improvement of national logistics competency. Needless to say, delays in customs clearance, border crossings, and pilferage in transit have a significantly adverse effect on the logistics performance.

If the customs clearance is processed in a fast and predictable way, cargos are more likely to be delivered to the final destinations on time. In addition, if the customs regulations and document requirements 
Table 1 Variables

\begin{tabular}{ll}
\hline Input / Output & Variables \\
\hline $\begin{array}{l}\text { Input of Stage 1 and Stage 3 } \\
\text { (Area for Policy Regulation) }\end{array}$ & Customs \\
& $\begin{array}{l}\text { Infrastructure } \\
\text { Services Quality }\end{array}$ \\
\hline $\begin{array}{l}\text { Output of Stage 1; Input of Stage 2 } \\
\text { (Service Delivery Performance) }\end{array}$ & Timeliness \\
\hline Output of Stage 2 and Stage 3 & Tracing \& Tracking \\
\hline
\end{tabular}

are streamlined, the shippers can prearrange their shipments with minimum efforts and costs. Redundant regulations and restrictions on customs clearance increase time and cost, which reduces the logistics competitiveness of a country in international business (Marti, Puertas and Garcia, 2014). The national policy environment critically affects logistics performance (Arvis et al., 2014). Thus, unnecessary regulations should be avoided in order to improve the national logistics competency (Lu and Lin, 2012). Reforming regulations and policies will reduce cost and time and enhance the reliability of deliveries.

'Infrastructure' refers to the quality of logistics infrastructure (e.g. roads, ports, railways, airports and IT systems). Infrastructure and customs procedures are very important for the improvement of logistics efficiency (Marti, Puertas, and Garcia 2014). High-quality infrastructure makes use of up-to-date equipment and contributes to on-time delivery, easy shipment arrangement and accurate cargo tracing \& tracking.

If IT systems are available to this process, transportation infrastructure may have fewer constraints on the customers and lead to better service quality. Keebler and Plank (2009) find that weak IT is one of the major determinants of undesirable logistics performance. Hausman, Lee and Subramanian (2013) suggest that information technologies, such as customs clearance processing systems and advanced cargo inspection systems, should be introduced for the benefit of reducing logistics cost and time. Arvis et al. (2014) prove that the quality of the information and communications technology infrastructures is the most important for better logistic performance through their survey. Eliminating unnecessary steps and speeding up the application process through IT is indispensable for stronger reliability among different parties involved in international business (Hausman, Lee and Subramanian, 2013).

Bakar et al. (2014) suggest that logistics needs to focus on infrastructure and border management for the smooth flow of inbound and outbound activities. Arvis et al. (2007) argue that efficient and bestmanaged transport routes and trade procedures should have technical and economic advantages. Supply chain decisions related to infrastructure in developing countries need to deal with poor transportation conditions, unavailability of warehousing facilities and insufficiency in distribution network systems (Foroughi, Kocakulah and Perkins, 2003).

'Service quality' is the third variable related to policy regulation. It stands for the competence and 
quality of logistics services from service providers. Global logistics service companies own many fixed assets, such as vehicles, vessels and cargo planes, which allows cargoes to arrive at the destination by the scheduled time and the shipment arrangement is relatively easy. Such high-quality service also includes well-organized tracing \& tracking systems which update the cargo movement on a real-time basis. Besides, if a country wants to be more competitive, it should encourage the development of third-party logistics to function and compete with the local service providers (Arvis et al., 2014).

Regarding the service delivery performance, the 'timeliness' variable means the frequency at which shipments are delivered to the consignees before the scheduled or expected delivery deadlines. The 'international shipments' variable is the degree of ease to make arrangement for competitively-priced shipments. The 'tracing \& tracking' variable is the availability to track and trace the consignments. These three variables are used as the output of Stage 1 and the input of Stage 2.

The last variable 'GDP per capita' is used as the output of Stages 2 and 3. GDP (Gross Domestic Product) is the most popular criterion used to represent and evaluate the output of an economy. GDP per capita is GDP divided by the midyear population. GDP is the sum of the gross values added by all resident producers in the economy plus all product taxes. GDP excludes those subsidies which are not included in the value of the products (Hernandez, 2006).

Table 2 shows the descriptive statistics of all the six variables for 157 countries.

Table 2 Descriptive Statistics

\begin{tabular}{cccccccc}
\hline Category & Customs & $\begin{array}{l}\text { Infra- } \\
\text { structure }\end{array}$ & $\begin{array}{l}\text { Service } \\
\text { Quality }\end{array}$ & $\begin{array}{l}\text { Time- } \\
\text { liness }\end{array}$ & $\begin{array}{l}\text { International } \\
\text { Shipments }\end{array}$ & $\begin{array}{c}\text { Tracing\& } \\
\text { Tracking }\end{array}$ & $\begin{array}{c}\text { GDP per } \\
\text { Capita }\end{array}$ \\
\hline Maximum Value & 4.21 & 4.32 & 4.19 & 4.71 & 3.82 & 4.17 & 110,665 \\
Minimum Value & 1.50 & 1.68 & 1.84 & 2.04 & 1.70 & 1.85 & 237 \\
Average & 2.73 & 2.77 & 2.86 & 3.26 & 2.87 & 2.91 & 14,969 \\
Standard Deviation & 0.59 & 0.65 & 0.57 & 0.57 & 0.48 & 0.57 & 20,997 \\
\hline
\end{tabular}

Sources: https://lpi.worldbank.org/; http://data.worldbank.org/indicator (Year: 2013)

\section{DEA Application and Discussion}

Output-oriented DEA models have been selected for this study since the improvement of the output is more desirable. The DEA solver developed by Cooper, Seiford and Tone (2007) is used for this study to analyze the logistics efficiency of the 157 countries. Table 3 shows the efficiency score, RTS and the reference set for Iraq.

Stage 1 evaluates the efficiency of supply chain service delivery. The input variables are related to policy regulation and the output variables are regarding service delivery performance. Iraq ranks the 22nd on CCR (technical evaluation) and 53rd on BCC (pure technical evaluation) out of the 157 countries. The level of Iraq's logistics performance is very unfavourable in consideration of the low input and output values in the raw data. As commented above, the current logistics in Iraq is very inefficient and requires dramatic 
Table 3 DEA Result of Iraq

\begin{tabular}{lllll}
\hline Stage & Efficiency & Score & Return to Scale (RTS) & Common Reference Set from CCR and BCC \\
\hline \multirow{3}{*}{1} & CCR & 0.98 & & \\
& BCC & 0.98 & IRS (Increasing RTS) & Kenya, Myanmar \\
& Scale & 0.995 & & Norway \\
2 & CCR & 0.10 & & \\
& BCC & 0.26 & IRS (Increasing RTS) & Qatar \\
\hline \multirow{2}{*}{3} & Scale & 0.39 & & \\
\hline
\end{tabular}

improvement. Meanwhile, Kenya and Myanmar are listed as the reference set in the CCR and BCC results. They could be used as the benchmarking targets but additional detailed study is required. Kenya and Myanmar are geographically advantageous in being connected with other countries. Likewise, Iraq also has this geographical advantage as its location is between Asia and Europe. It has the potential ability to function as the logistics hub in this region, if logistics environment (e.g., Customs formalities, transportation facilities and delivery equipment) is improved within the country. In addition, Kenya ranks second as an outperformer among all low-income countries according to Arvis et al. (2014). Its output value scores (including international shipments, timeliness, and tracing \& tracking) are much better than those of Iraq. The SE of Iraq is 0.995 and ranks 43rd. IRS under RTS indicates that Iraq needs to improve its efficiency by increasing inputs for customs reformation and logistics infrastructure investment in order to achieve better logistics service quality.

Stage 2 analyses the impact national logistics efficiency on the local economy. The input variables include timeliness, international shipment, and tracing \& tracking, which are the output variables of Stage 1 and related to the service delivery performance. GDP per capita is used as the output variable for this stage. The CCR score is 0.1 , which ranks 70th among the 157 countries. The BCC score is 0.26 ranking 78 th. The SE score of Iraq is 0.39 also ranking the 78th. Norway is employed as the reference set for the CCR and BCC analyses. This result implies that Iraq is relatively very inefficient compared to the efficient frontier markets. Effective measures are to be taken for improving its service delivery performance in terms of timeliness, international shipments, and tracing \& tracking.

Stage 3 evaluates the overall efficiency of the national logistics. The input variables are customs, infrastructure and services quality, which are the input variables of Stage 1. GDP per capita is used as the output variable for this stage. The CCR score of Iraq is 0.12 and ranks the 65th. The BCC score is 0.44 and ranks the 36th. Qatar is shown as the reference set in the CCR and BCC results. Qatar is another country in the Middle Eastern area with a dominant oil and gas industry in its national economy. Iraq is supposed 
to adopt this benchmarking target since both countries are located in the same region and are among the largest exporters of oil and gas. The SE of Iraq is 0.27 and its RTS is increasing as well. As a result, Iraq should improve its logistics efficiency through increasing its inputs in streamlining its customs procedures and enhancing its infrastructure to better serve its national economic growth.

Table 4 DEA Projection Result of Iraq

\begin{tabular}{|c|c|c|c|c|c|}
\hline Stage & DEA & Input / Output & Value & Projection & Difference $(\%)$ \\
\hline \multirow{6}{*}{1} & \multirow{3}{*}{ CCR } & Timeliness & 2.85 & 2.92 & 2.33 \\
\hline & & International Shipments & 2.31 & 2.36 & 2.33 \\
\hline & & Tracing \& Tracking & 2.31 & 2.44 & 5.73 \\
\hline & \multirow{3}{*}{$\mathrm{BCC}$} & Timeliness & 2.85 & 2.90 & 1.85 \\
\hline & & International Shipments & 2.31 & 2.35 & 1.85 \\
\hline & & Tracing \& Tracking & 2.31 & 2.47 & 6.90 \\
\hline \multirow{2}{*}{2} & $\mathrm{CCR}$ & GDP per Capita & 6957.35 & 67459.63 & 869.62 \\
\hline & $\mathrm{BCC}$ & GDP per Capita & 6957.35 & 26327.82 & 278.42 \\
\hline \multirow{2}{*}{3} & $\mathrm{CCR}$ & GDP per Capita & 6957.35 & 57782.98 & 730.53 \\
\hline & $\mathrm{BCC}$ & GDP per Capita & 6957.35 & 15720.05 & 125.95 \\
\hline
\end{tabular}

Table 4 shows the DEA projection result of Iraq. Based on the result of the CCR projection values, Iraq needs to improve its timeliness by $2.33 \%$, international shipments by $2.33 \%$ and tracing \& tracking by $5.73 \%$ at Stage 1. The BCC result shows that Iraq needs to improve its timeliness by $1.85 \%$, international shipments by $1.85 \%$, and tracing \& tracking by $6.9 \%$. The item "tracing \& tracking" shows the biggest difference between the current value and the projection. The focus needs to be directed to the strengthening of the supply chain service delivery.

\section{Suggestions for Improvement}

According to the DEA analysis and the investigation on the logistics of the Iraqi oil and gas industry, the following recommendations are made regarding the improvement of the efficiency in its supply chain service delivery:

\section{Timeliness}

Many international companies undertaking projects in Iraq have suffered from the delayed delivery of the required materials and equipment at the project sites. The delay not only prolongs the entire project but also leads to extra costs beyond the project budget for penalty, storage and liquidated damages with contractors in huge amount. The main reason for such delay is the inefficient customs processing in Iraq. Once again, Iraq needs to focus on streamlining its customs procedures and adopting the global standard in advanced 
countries for better logistics performance.

The current customs processing in the Iraqi oil and gas industry requires numerous approvals from several Iraqi governmental departments. This has caused serious delays in customs clearance, retards the delivery of the merchandise, and thus intensifies the overall congestion. The streamlining of the customs processing helps solve this problem. All required documents for customs clearance should be submitted to the Iraq port authorities directly for expedition. Currently, pre-approvals from the Iraqi government are mandatory and all documents are submitted to MdOC in Baghdad. The authorized staff should stay at the ports to offer advice on the application and give relevant approvals. This will shorten the customs clearance process to a large extent. The installation of bonded warehouses is possibly beneficial for the improvement of the congestion situation at the ports. The customs clearance for the materials and equipment imported to the Iraq ports can be conducted at the bonded warehouses outside the ports. This will alleviate the congestion at the ports and reduce the customs clearance duration.

Many documents are required for customs clearance in Iraq as reviewed in Chapter 2. Unnecessary document requirements need to be abandoned in order to realize timely customs clearance. For example, there is a process called "obtaining the 2nd delivery order" . It is a document issued by the Ministry of Transport after the shipment arrival. After submitting the application to the consignee (government department) for endorsement, it may take several days or a week to obtain the approval. Iraq should follow the international practice and allow the endorsement process for the shipping documents to commence without such delivery orders so that all documents can be prepared beforehand at the entry point and customs clearance can take place directly right after the delivery orders are received.

There are some strict regulations on the shipping documentation for customs clearance in Iraq, which causes the timeliness failure. For example, Iraqi customs requires the legalization of all commercial invoices and certificates of origin, which must be attested by the Iraqi embassy in the country of origin. But in some cases, it is impossible to complete the legislative process in the country of origin. Iraqi customs should benchmark regulations of the advanced countries as many countries do not require such a legislative process.

As mentioned above, vehicles for transportation are moving very slowly in Iraq and it takes a much longer time than expected for the imported merchandise to arrive at the final destination due to the poor road condition and numerous checkpoints within the country. Iraqi roads have deteriorated during the war. Many sections were destroyed and damaged as a result of the military operations. Continuous unstable security situation worsens the current condition and hinders the rebuilding and the recovery of the roads.

Another key reason for the on-time delivery failure in Iraq is the lack of IT systems for the customs clearance process. Customs processing in Iraq is managed without proper IT systems, which means the documents are not submitted and processed online. Customs staff and the logistics service providers have to hand-carry the shipping documents to the related departments for customs clearance, even when they have to travel from Baghdad to Basra. Shipping documents are lost sometimes, which leads to a very serious delay in the customs clearance. Thus, it is of critical significance for Iraq to implement an effective IT system to facilitate the import and export processes. In developed countries, using IT systems for customs clearance has been taken for granted. The submission and processing of the necessary documents are conducted online. The 
online processing of the customs processing, e.g., shipments documentation registration, customs declaration and approvals, will largely improve the timeliness of customs clearance in Iraq.

\section{International shipment}

Table 5 shows indicators of trading across the borders with a comparison with the neighbouring countries of Iraq. In Iraq, exporting and importing a standard container of goods require 10 documents for each process. It takes 80/82 days and costs 3,550/3,650, respectively. Iraq stands the 178th in the global ranking among 189 economies on the easiness degree to trade across borders (World Bank Group, 2015).

Table 5 Indicators of Trading Across Borders

\begin{tabular}{lllllllll}
\hline Indicator & Iraq & Egypt & Iran & Jordan & Oman & $\begin{array}{l}\text { Saudi } \\
\text { Arabia }\end{array}$ & U.A.E & $\begin{array}{l}\text { Best Performer } \\
\text { Globally }\end{array}$ \\
\hline $\begin{array}{l}\text { Documents for } \\
\text { Exportation (sets) }\end{array}$ & 10 & 8 & 7 & 5 & 7 & 6 & 3 & Ireland (2) \\
$\begin{array}{l}\text { Time before } \\
\text { Exporting (days) }\end{array}$ & 80 & 12 & 25 & 12 & 10 & 13 & 7 & Five Economies (6) \\
$\begin{array}{l}\text { Cost for } \\
\begin{array}{l}\text { Exportation } \\
\text { (US } \$ \text { per container) }\end{array}\end{array}$ & 3550 & 625 & 1350 & 825 & 765 & 1285 & 665 & Timor-Leste (410) \\
$\begin{array}{l}\text { Documents for } \\
\text { Importation (sets) }\end{array}$ & 10 & 10 & 11 & 7 & 8 & 8 & 5 & Ireland (2) \\
$\begin{array}{l}\text { Time before } \\
\text { Importing (days) }\end{array}$ & 82 & 15 & 37 & 15 & 9 & 17 & 7 & Singapore (4) \\
$\begin{array}{l}\text { Cost for } \\
\begin{array}{l}\text { Importation } \\
\text { (US } \$ \text { per container) }\end{array}\end{array}$ & 3650 & 790 & 1555 & 1235 & 700 & 1309 & 625 & Singapore (440) \\
\hline
\end{tabular}

Source: World Bank Group (2015)

Currently, international oil and gas companies are experiencing difficulties to arrange shipments for their merchandise in Iraq, as most cargos must be consigned to the government authority for approvals in order to prepare the shipments. In addition, there are clear indications available on the set of procedures required for this application of approval. Besides, poor infrastructure (e.g., roads and port equipment) and the unstable security situation hinder the shipments from prompt delivery.

As mentioned above, Umm Qasr port, which is the main entry point in Iraq, lacks the capacity to handle all materials. Since the number of projects there, are expanding and the demand for shipment is predicted to increase there, the port capacity needs to be enhanced to meet this need. Furthermore, the equipment at Umm Qasr port is obsolete and often non-operational or unfunctional. It adversely affects the performance of the port as an importing entry.

Meanwhile, Khor Al Zubair port, which is the second largest port in Iraq, has the relatively up-to-date equipment and enough capacity for the shipment of more goods. However, international shipping liners are 
not using it frequently due to the shallow berthing drafts at the port. Deeper draft at Khor Al Zubair port is required for giant vessels. Moreover, Khor Al Zubair port generally handles bulk cargoes only. It should be equipped for higher capability to handle container cargos as well. Fortunately, Iraq is now developing the Al Faw grand port in southern Basra, which will increase the whole capacity of the country to handle international shipments.

Iraq may derive a benefit from its railway network if obsolete sections are restored and renovated. At the current stage, trucking is the dominant option for its overland transportation. Rehabilitating and extending the railway network plays an important role in the improvement of its logistics performance due to its geographical advantage to linking Asia and Europe.

As addressed above, customs procedure is one of the biggest bottlenecks for arranging shipments. No clear written rules are available for detailed customs requirement. Customs staffs may require changes in the document formats and translation. This intuitive decision-making may incur additional costs and processing time for customs clearance. The current customs law in Iraq was enacted in 1984 and lacks transparency. In the law, the practice at the customs are not well-regulated and the right of the international companies are not protected.

\section{Tracing \& Tracking}

Tracing \& tracking service is not much available in Iraq. Some shipments are lost or stolen during transportation, which may bring about unexpected delays in the project completion. A few logistics service providers make use of an online tracing-and-tracking system. But most of local logistics companies do not have such advanced systems so no after-service is guaranteed.

Iraq should utilize the third-party logistics (3PL) or the fourth-party logistics (4PL) to improve its logistics performance and international reputation. The Iraqi government needs to encourage global logistics companies to do business in Iraq to ensure the competitiveness of its logistics services.

\section{GDP}

Table 4 shows that GDP per capita needs to be improved by $870 \%$ and $278 \%$ based on the CCR and BCC results in Stage 2. The analysis result of Stage 3 further indicates that Iraq should improve its GDP per capita by $731 \%$ and $126 \%$ based on the CCR and BCC results to become an efficient country. As IRS is an output of the DEA result, Iraq can grow its economy by improving its logistics performance, which may require a re-engineering process of customs administration, investment in infrastructure, adoption of effective online systems, assurance of on-time delivery, streamlining regulations for shipment arrangement, enhancement of tracing \& tracking capability. Currently, several oil and gas projects are being undertaken in Iraq by international oil and gas companies, such as Shell, BP, Gazprom, Lukoil, Petronas, KOGAS, and Eni. These projects need to import equipment and materials in large quantity from abroad for developing oil and gas sites. International dealers have suffered greatly from the delayed delivery of equipment and materials and the unexpected cost caused by poor logistics service. Iraq should take effective measures to 
solve this problem in order to better facilitate international business and thereby expand its economy.

\section{Conclusions}

Improving logistics efficiency plays a very important role in increasing national competitiveness and ameliorating business environment. The evaluation of logistics performance helps to improve the efficiency of supply chains, infrastructures, services, procedures and regulations. Most international companies undertaking oil and gas projects in Iraq have suffered due to its inefficient logistics, and there is huge scope for the improvement.

This paper investigates the current logistics situation in the Iraqi oil and gas industry using a twostage DEA analysis and provides practical recommendations for improvement. Comparative evaluation is conducted on the supply chain service delivery (Stage 1), the national logistics efficiency to the local economy (Stage 2) and the national logistics efficiency (Stage 3) among 157 countries. The results of this research can help the Iraqi government to make decisions on how to improve its logistics environment and offers advice to foreign investors in the business environment in Iraq before entering the market. Iraq should reform its customs clearance procedures, and increase its investment on logistics infrastructure, i.e., rehabilitation and extension of roads, airports and railways, increasing capacity at seaports, implementing advanced IT systems. Furthermore, Iraq should improve the competitiveness of its logistics services by attracting global logistics service providers to Iraq and adopting advanced global practice from developed countries.

The DEA projection result shows that tracing \& tracking is the most important variable for improving the efficiency of the supply chain service delivery. It also reveals that Qatar could be taken as one of the benchmark countries. Both of the two countries are located in the same region, and the oil and gas industry functions as an irreplaceable part of the national economies.

Future studies are supposed to put an emphasis on the following points in order to fulfil the benchmarking goals of Iraq in its logistic performance improvement:

1) Each recommendation in this study should be implemented practically. The top management from each stakeholder of the country should get fully involved in frequent discussion on this issue to ensure the implementation of the necessary requirements. These administrative sectors include the Ministries of Oil, Finance (General customs and Tax office), Trade, Transport and the Intelligence Management. Without the support of the authorities, it is difficult to make any substantial progress in the current situation. The Prime Ministers need to attend such discussions for developing consensus among the different stakeholders and reaching final decisions on huge amount of investment on the rehabilitation and renovation of the country.

2) The DEA result provides a reference set which can be considered as a benchmarking target. Studying the logistics performance of these countries and conducting comparisons in detail will be a sound approach for more effective proposals on the improvement for Iraq.

3) The availability of the actual data on logistics in Iraq is very low, therefore, there is a huge delay in research regarding the evaluation of its performance. Applying the actual data to measure its efficiency is of crucial value for the future study. Moreover, applying other analysis models (e.g., balanced scorecard, 
SCOR models) will throw light on the issue and are meaningful for developing more practical implications.

\section{References}

Arvis, J., Mustra, M. A., Panzer, J., Ojala, L. and Naula, T., 2007. "Connecting to Compete 2007: Trade Logistics in the Global Economy - The Logistics Performance Index and Its Indicators", World Bank. doi: http://siteresources . worldbank.org/INTTLF/Resources/lpireport.pdf.

Arvis, J., Saslavsky, D., Ojala, L., Shepherd, B., Busch, C. and Raj, A., 2014. "Connecting $\quad$ to $\quad$ Compete 2014: Trade Logistics in the Global Economy - The Logistics Performance Index and Its Indicators", World Bank. Retrieved on Dec. 12, 2017, doi: http://d21a6b425f3bbaf588249ec594b5f9dc5376fe36450505ae1164.r12.cf2.rackcdn.com/LPI_Report_2014.pdf .

Bakar, M. A. A., Jaafar, H. S., Faisol, N. and Muhammad, A., 2014. "Logistics Performance Measurements - Issues and Reviews", 19th International Symposium on Logistics at Ho Chi Minh City, Vietnam, July 6-9.

Chaowarat, W., Piboonrugnroj, P. and Shi, J., 2013. "A Review of Data Envelopment Analysis (DEA) Applications in Supply Chain Management Research", Proceedings of the 2013 IEEE IEEM, pp. 975-980.

Charnes, A., Cooper W. W. and Rhodes E., 1978. "Measuring the Efficiency of Decision Making Units", European Journal of Operational Research, Vol. 2, pp. 429-444.

Cook, W. D., Kress, M. and Seiford, L. M., 1996. "Data Envelopment Analysis in the Presence of Both Quantitative and Qualitative Factors", The Journal of Operational Research Society, Vol. 47, pp. 945-953.

Cook, W. D. and Zhu, J., 2006. "Interfaces with Other Disciplines - Rank Order Data in DEA: A General Framework", European Journal of Operational Research, Vol. 174, pp. 1021-1038.

Cooper, W.W., Seiford L.M. and Tone, K., 2006. Introduction to Data Envelopment Analysis. Springer.

Cooper, W. W., Seiford, L. M. and Tone, K., 2007. A Comprehensive Text with Models, Applications, References and DEA-Solver Software. Springer.

Cook, W. D., Tone, K. and Zhu, J., 2014. "Data Envelopment Analysis: Prior to Choosing a Model", Omega, Vol. 44, pp. 1-4.

Foroughi, A., Kocakulah, M. C. and Perkins, W. C., 2003. "Performance Metrics: Key to Success in Global Supply Chain Management", Journal of Transnational Management Development, Vol. 8, No. 3, pp. $35-45$.

W. H., Lee, H. L. and Subramanian, U., 2013. "Impact of Logistics Performance on Trade", Production and Operations Management, Vol. 22, No. 2, pp. 236-252.

Hernandez, I., 2006. Fridays Academy: Macroeconomic concepts. The World Bank IBRD Data. http: //blogs.worldbank.org/growth/fridays-academy-macroeconomic-concepts, accessedonJan.20, 2017.

Iraqi Ministry of Planning, 2013. National Development Plan 2013-2017. Ministry of Planning Republic of Iraq. doi: http://www.mop.gov.iq/mop/index .jsp?sid=1\&id=642\&pid=553 .

Jalalvand, F., Teimoury, E., Makui, A., Aryanezhad, M. B. and Joali, F., 2011. "A Method to Compare 
Supply Chains of an Industry", Supply Chain Management: An International Journal, Vol. 16, No. 2, pp. 82-97.

Keebler, J. S. and Plank, R. E., 2009. "Logistics Performance Measurement in the Supply Chain: A Benchmark", Benchmarking: An International Journal, Vol. 16, No. 6, pp. 785-798.

Liu, J. S., Lu, L. Y. Y., Lu, W. M. and Lin. B. J. Y., 2013. "Data Envelopment Analysis 1978-2010: A Citation-based Literature Survey", Omega, Vol. 41, No. 1, pp. 3-15.

Lu, C. and Lin, C., 2012. "Assessment of National Logistics Competence in Taiwan, Vietnam, and Malaysia", The Asian Journal of Shipping and Logistics, Vol. 28, No. 2, pp. 255-274.

Marti, L., Puertas, R. and Garcia, L., 2014. "Assessment of National Logistics Competence in Taiwan, Vietnam, and Malaysia", Applied Economics, Vol. 46, No. 24, pp. 2982-2992.

Rantasila. K. and Ojala. L., 2015. "National-level Logistics Costs: An Overview of Extant Research", International Journal of Logistics Research and Applications: A Leading Journal of Supply Chain Management, Vol. 18, No. 4, pp. 1-12.

Reiner, G. and Hofmann, P., 2006. "Efficiency Analysis of Supply Chain Processes", International Journal of Production Research, Vol. 44, No. 23, pp. 5065-5087.

Wang, T., 2014. "Estimation of Cross-country Logistics Efficiency on Macro-level", Master Thesis, ChungAng University.

Wong, W. P. and Wong, K. Y., 2007. "Supply Chain Performance Measurement System Using DEA Modelling", Industrial Management \& Data Systems, Vol. 107, No. 3, pp. 361-381.

Wong, W. P. and Wong, K. Y., 2008. "A Review on Benchmarking of Supply Chain Performance Measures", Benchmarking: An International Journal, Vol. 15, No. 1, pp. 25-51.

World Bank Group, 2015. "Doing Business 2015: Going Beyond Efficiency" World Bank. doi: http://www.doingbusiness .org/ /media/GIAWB/Doing\%20Business/Documents/Annual-Reports/ English/DB15-Full-Report.pdf .

Zhu, J., 2014. Quantitative Models for Performance Evaluation and Benchmarking: Data Envelopment Analysis with Spreadsheets (3rd ed). Springer. 